\title{
The Globalization of Citizen Journalism on Internet and in Traditional News
}

\author{
${ }^{1}$ Ozewe Banke, R., ${ }^{2}$ Yahaya Ogbe Agbaji and ${ }^{1}$ Laura Haruna-Banke, \\ ${ }^{I}$ NTA College, Jos Plateau State Affiliated to Ahmadu Bello University Zaria, (ABU), Kaduna State, Nigeria. \\ ${ }^{2}$ Tom Adaba Library, NTA Television College, Jos (Affiliated to Ahmadu University, Zaria, Kaduna State -
} Nigeria)

\begin{abstract}
The globalization of Citizen Journalism on Internet and in Traditional news has been a research topic over the years by numerous scholars world over. Technologies and work practices are also changing rapidly, making it difficult to discern any sense of a consolidation of practices since the development of the World Wide Web, its colonisation by commercial news providers and the ballooning of online usage in the mid1990s. Advocates of citizen journalism hail it as an opportunity to improve journalism, making it more transparent and democratic as the audience can check the facts presented and easily correct or add to the original article. On citizen journalism sites such as Spot. us or Broowaha.com readers can also decide which stories will be investigated and where they will be placed on the site. During the 2008 U.S. presidential election campaign, a citizen journalism TV channel called Current TV partnered with Twitter during the candidates' debates so that viewers could tweet their comments, which were shown live on screen Andrew, (2007). Role hitherto played exclusively by the traditional media are now performed by citizen journalism through the virtual community. Citizen journalism embraces all the social media platforms such as Face Book, YouTube, Twitter, MySpace and the Blogosphere.
\end{abstract}

Keyword: Globalization, Citizen Journalism, Internet and Traditional

\section{INTRODUCTION}

According to Serena C. (2000) a citizen journalist can be described as an individual who intends to publish information meant to benefit a community. Citizen journalism has further been described as the individual "playing an active role in the process of collecting, reporting, analyzing and disseminating news and information." In their report We Media: How Audiences are Shaping the Future of News and Information, Shayne Bowman and Chris Willis write further that "the intent of this participation is to provide independent, reliable, accurate, wide-ranging and relevant information that a democracy requires." According to Joyce Nip, citizen journalism, sometimes called online citizen journalism, can also be defined as a process in which people were entirely responsible for gathering content, along with envisioning, producing and publishing the news product.

Role hitherto played exclusively by the traditional media are now performed by citizen journalism through the virtual community. Citizen journalism embraces all the social media platforms such as Face Book, YouTube, Twitter, MySpace and the Blogosphere. All the content generated from these social media platforms alongside comments from the audience and message board postings, pictures and video uploads constitute what is now known as the User Generated Content (UGC), which is a feature closely associated with the citizen journalism concept.

Fackson B. (2010) ground breaking exploratory study on 'Citizen Journalism and Democracy in Africa' defines citizen journalism as "a rapidly evolving form of journalism where common citizens take the initiative to report news or express views about happenings within their community". Fackson identifies two types of citizen journalism - institutional and non-institutional. The non-institutional forms place the individual at the core of the practice, one that lends itself to the social networking platforms where private citizens generate content and share among a network of friends and online. On the other hand, institutional citizen journalism has a defined organizational structure and some minimal constraint. A good example is the opening up of most traditional media websites allowing traditional journalists to interact via comments and feedback using citizen journalism platforms. The BBC and The Guardian of London have fully embraced in different ways the institutional form of citizen journalism and its practice is widespread in the traditional media to different degrees.

Citizen journalists can be accidental journalists, advocacy journalists and grassroot journalists. Ross and Cormier, (2010) provided further insight into these different forms of citizen journalism. Advocacy journalism according to them is "one that adopts a viewpoint; journalism with an intentional and transparent 
bias although it must be distinguished from propagandist reporting", while accidental journalists are people caught unexpectedly in the middle of an event and who then make use of the social networking websites to broadcast their material.

However, to a large extent what we see today is a widespread citizen journalism practice that combines the features of accidental, advocacy, participatory and grassroots journalism. In Nigeria, we have such sites as Sahara Reporters which proudly announces its advocacy bent, but also absorbs all these other inputs. The same can be said of the first global online citizen journalism site in South Korea, OhmyNews.com. As far as we can infer, there is no one single definition of citizen journalism - it is varied, but with very distinguishable characteristics. Though the debate over classification continues, there is an uncontestable central agreement: the direct involvement, ability, opportunity and right of the individual to produce content and disseminate it. But it is to Dan G. (2006) regarded widely as the father of Citizen Journalism, that we must turn to for answers on the nature of citizen journalism, it's essential characteristics and the potential and future of this new genre. The emergent ecology of citizen journalism is linked to crisis reporting. During political criseslike those in Kenya and Iran, natural disasters like the tsunami and earthquake in Haiti,terrorists attacks such as the September 11 attacks on America and the July 2005 London attacks, we saw citizen journalism or "accidental journalism" as many would regard it at work. Ordinary citizens at the wrong place at the right time have risen to the challenge and have committed "acts" of journalism by using new communication "toolkit" to capture footage of these important developments as they unfolded adding depth, timeliness and comprehensiveness. Dan Gillmor captured this epoch when he said:

Something else, something profound was happening this time around: news was being produced by the regular people, who had something to say and show, and not solely by the 'official' news organizations that had traditionally decided how the first draft of history would look. This time, the first draft of history was being written in part by the former audience.

According to Gillmor, "the collision of journalism and technology is having major consequences on journalists, newsmakers and the audience'. From Iran to Nairobi, from the USA to Cairo and from Lagos to London through Japan to the Americas, citizens have become empowered to communicate and set the news agenda Dan G. (2006). Consequently, the great possibilities for participatory and more deliberative processes of democracy this development holds have led to increased academic interest in examining the tools and processes that have opened this new vista in citizenship participation.

\section{Media Globalization: Issues of Scale and Homogeneity}

One major fault line lies within the broader context of 'media,' where journalism has been seen as providing flows of information and transnational connections. That makes it a key factor in the phenomenon of 'media globalization.' McLuhan in gave us the enduring image of the 'global village,' a quasi-utopian idea that has seeped into such theorizing about the contribution of media. The metaphor brings expectations of an extensive, unitary community, with a corresponding set of universal, global values, undistorted by parochial interests and propaganda. The interaction of world media systems, however, has not as of yet yielded the kind of transnational media and programs that would support such 'village'-worthy content (Ferguson 1992; Sparks 2007). In fact, many of the communication barriers show no signs of coming down, with many specialized enclaves becoming stronger. In this respect, changes in media reflect the larger crux of globalization that it simultaneously facilitates certain 'monoculture' global standards along with the proliferation of a host of microcommunities that were not possible before. In a somewhat analogous example, the global wine trade has led to convergent trends in internationally desirable tastes but also allowed a number of specialized local wineries to survive and flourish through the ability to reach global markets.

The very concept of 'media globalization' suggests that we are not quite sure if media lead to globalization or are themselves the result of it. In any case, giving the media a privileged place in shaping a globalized future has led to high expectations for international journalism, satellite television, and other media to provide a workable global public sphere, making them an easy target if they come up short.

\section{Searching for the Global in Journalism}

When considering globalization and journalism, it is tempting to come up with new categories of media, practice, professionals, and content and elevate them to 'global' status. To classify 'global media,' for example, or find a group that can be identified as 'global journalists' has presented a definitional challenge, given their dispersal and inter-connectedness (Reese 2001, 2008). Who qualifies as a 'global journalist' and is this just a new term for 'foreign correspondent'? This may ultimately be more of a provocative concept than a strictly defined empirical category. A volume entitled the global journalist, for example, was in fact a countryby-country survey of professionals (Weaver 1998), with few attempts then or now to explicate the concept. 'Global media' have been variously defined as those having a global reach or in being owned by global 
transnational corporations (Herman and McChesney 1997). Global news media content also suffers from difficulty separating it out from other forms, although scholars have been experimenting with identifying in content analyses certain intrinsically global issues and perspectives in the news (e.g. Berglez 2008). Some have focused on how certain 'global' events such as summits are covered, while others have begun paying closer attention to the journalistic practices that map onto supranational governance, finding for example that the Financial Times is a crucial arbiter and agenda-setter for European Union news (Corcoran and Fahy 2009).

\section{Conceptualizing the 'Global'}

For many, 'global' means big. That goes too for the global village perspective, which emphasizes the scaling dimension and equates the global with 'bigness,' part of a nested hierarchy of levels of analysis based on size: beyond local, regional, and national. Against this expectation that media report and reach the entire globe, little evidence exists for a world communication system with an undistorted view of the world. The global village implies global consciousness, which implies a homogeneity of world views, or at least a diverse "dialog of cultures.' Again, the global media system, particularly international broadcasting, does not live up to that hope: homogenization loses out to domestication.

The global village idea even colors the interpretation of related research concepts. The 'networked society' of Manuel Castells (2007), for example, rather than seen as yielding different lines of cross-border articulation can be interpreted to require a giant cluster of inter-linked world, state, and cultural entities. 'Glocalization,' a popular concept in this literature, can be seen not as the inevitable interplay between local and cultural forces from a distance, but as the uniform imposition of a global (village) standard across a range of local circumstances. These interpretations, however, obscure the real complexity of globalization. Satellite news channels, as mentioned earlier, have figured prominently in the 'media globalization' debate. This has led to these platforms often being regarded as a 'space apart' in a new 'global' realm. Volkmer (1999), for example, ties global news to an emerging world civil society structure. In her study of CNN International, she argues that global political communication constructs a global public sphere, from which emerges global civil society. This global platform, she says, supports the communication

\section{Journalism and Globalization}

According to Volkmer (2002) in a new 'sphere of mediation,' she says journalists work to mediate between nation and extra-societal global political space, between the national and the global, requiring new roles for journalists. Hjarvard (2001) is among those declining to declare the global public sphere a new autonomous zone, claiming it is rather a process of restructuring and recasting public communication. Cottle and Rai (2008) also focus on these satellite news channels but explore their content more directly (something they argue has been long needed) (Cottle and Nolan 2007).

To classify 'global media,' for example, or find a group that can be identified as 'global journalists' has presented a definitional challenge, given their dispersal and inter-connectedness (Reese 2001, 2008). Who qualifies as a 'global journalist' and is this just a new term for 'foreign correspondent'? This may ultimately be more of a provocative concept than a strictly defined empirical category. A volume entitled "The global journalist" for example, was in fact a country-by-country survey of professionals (Weaver 1998), with few attempts then or now to explicate the concept. 'Global media' have been variously defined as those having a global reach or in being owned by global transnational corporations (Herman and McChesney 1997).

Global news media content also suffers from difficulty separating it out from other forms, although scholars have been experimenting with identifying in content analyses certain intrinsically global issues and perspectives in the news (e.g. Berglez 2008). Some have focused on how certain 'global' events such as summits are covered, while others have begun paying closer attention to the journalistic practices that map onto supranational governance, finding for example that the Financial Times is a crucial arbiter and agenda-setter for European Union news (Corcoran and Fahy 2009). Other studies of the sociology of news have examined how 'global media gatekeepers' affect the flow of news and information. These have included observations of editorial. Citizen Journalists tend to bring themselves into the story; many see themselves as citizen activists. Some happen to be at the 'wrong place at the right time', such as the people caught up in Hurricane Katrina in August 2005, who emailed their personal accounts, pictures and videos taken with their mobile phones to mainstream media like CNN and the New York Times, as well as dedicated citizen news sites such as NowPublic.com. Others are very pro-active newsgatherers, who attend and report on specific events, ranging from local town hall meetings for a hyperlocal site, to protests at a G8 conference for Indymedia.org. Journalism is usually not their main occupation, and only few get paid for their efforts. 


\section{A brief Origination of Citizen Journalism}

Some scholars trace the European and U.S. origins of citizen journalism back to 17th and 18th century pamphleteering. What makes it so much more powerful in the 21st century; however, is the speed, low cost and global reach with which topics can be brought to the national and international news agendas, including issues that those in power would prefer to be ignored. According to its advocates, this is one of the great democratic opportunities of citizen journalism.

At the same time, many mainstream media organizations are under financial pressure, especially the newspaper industry, and have cut jobs on investigative and foreign desks. In some countries, including the United States, many local newspapers are closing down. People increasingly feel that a highly concentrated and controlled mass media no longer provides the information relevant to their lives but are following commercial and political aims. In countries with repressive governments, citizens become weary of the official news that is served up to them, as the internet provides an alternative source to state-controlled propaganda. This is where citizen journalists can fill a void.

Citizen journalism came to international prominence during times of crisis: the attacks on New York City and the Pentagon on 11 September 2001 were the first time that people looked to the web for eye witness reports, some of which were also incorporated by mainstream news. Ten, during the 2004 Asian tsunami, the term "citizen journalism" was used for the first time as photos and videos which tourists had uploaded on their personal blogs were used on television and in print Aaron, (2010).

\section{Professionalism in Journalism}

Even without the existence of MA institutions citizens or journalists could theoretically hold the media accountable. But what are the principles media should be held accountable to? As the media market in Syria has only been opened up recently for private publications and - in a limited way - for radio stations and TV channels, journalism has to struggle with a high degree of insecurity. There is not a clear state media policy. Censorship is arbitrary, which makes working in journalism more risky. Codes of ethics are not available. Senior journalists who might act as role models usually grew up in the socialist era, are mostly state employees, and are rarely involved in the changes that take place in the journalism field (Fengler 2007: 25). One of our interviewees describes the situation vividly:

"Baladna newspaper was stopped for three months. Later it was agreed through middlemen connected to the security that someone called Samir who work in Al Hayat will pass by every night to carry out a security check on the edition. He might cancel a whole report, which we need to find a substitute for, or cancel slight news or a word. It goes like this- once he enters the newspaper he does not entangle with us about the newspaper's course of action; [...] You may write an article which the editor will cancel in its entirety, or you may choose a subject or an opinion which will be rejected at all. This censorship is not always security-based; it could as well be based on personal motives. For example if I carry out a report on cinema in Syria and I would inquire the opinion of a producer disliked by the editor or himself ... so censorship is governed by personal likes and dislikes... Other censorship practices are ridiculous. We should not conduct a report about the deteriorating services in Al Assad district because of the name, so we would rename it with the neighboring district of Harasta. You know that at one time the cartoon film Lion was banned in Syria [Lion is "Assad" in Arabic and could be referred to President Al-Assad]. Another case was about garbage collectors (in Syria we do not have recycling). This garbage is fragmented then redistributed and sold through big companies to abroad, so we cannot call them zabbaleen [garbage collectors] as this hampers the image of national economy, but hygiene labor." (Perthes 2004: 105)

Another problem for Syrian journalism is the lack of access to information. The official communication policy towards the media is weak and sometimes selective besides the fact there is not an access to information law in Syria. Thus, information and validations are both difficult to access. The advent of the Internet in Syria, followed by citizens' contributions on websites, has provided important alternative news sources.

\section{Can Citizen Journalism be Better Journalism?}

Advocates of citizen journalism hail it as an opportunity to improve journalism, making it more transparent and democratic as the audience can check the facts presented and easily correct or add to the original article. On citizen journalism sites such as Spot.us or Broowaha.com readers can also decide which stories will be investigated and where they will be placed on the site. During the 2008 U.S. presidential election campaign, a citizen journalism TV channel called Current TV partnered with Twitter during the candidates' debates so that viewers could tweet their comments, which were shown live on screen Andrew, (2007).

In times of economic crisis and decreasing audiences, particularly among young people, the vast majority of mainstream media has encouraged the active involvement of non-professional journalists in three main ways: encouraging comments on an existing news piece crowdsourcing, where a reporter asks the general 
public to provide additional information to complete a story, or to help check facts uploading content through specific applications on websites or creating dedicated citizen journalism sites, such as CNN iReport (Deuzer, (2009). This not only saves costs but makes the research process more transparent, leading to greater trust from the audience as well as brand loyalty (Bowman and Willis, (2003). "Smart news organizations are engaging audiences and opening themselves up to the conversation our audiences clearly want", says Helen Boaden, 2009 BBC Head of News. This engagement also offers mainstream media a more varied catalogue of sources. Te $\mathrm{BBC}$ has invested in a dedicated UGC hub, which deals with about 12,000 emails and 200 photographs and videos per day, on the basis that "someone out there will always know more about a story than we do".

Furthermore, citizen journalism can help "[expand] the ideological spectrum for news audiences". Eye witness reports from ordinary people provide a variety of personal points of view, at times contradicting official statements. One of the most famous bloggers during the first years of the War in Iraq, (Babalola, 2002) for example, was Salam Pax (pseudonym), an Iraqi student, who through his blog "Where is Raed" gave an insight to his everyday life-including bombings and disappearances of people-inside Baghdad before and after the U.S. invasion, often contradicting the official statements of the U.S. and United Kingdom governments. He quickly gained a large number of regular followers, among them mainstream UK media such as the BBC and the Guardian, which regularly featured his reports. In contrast to other news stories, his accounts were very personal, making this international event less abstract for people outside Iraq.

In repressive countries, eye witness reports and images taken by ordinary citizens are often the only testimony available and can help influence international politics. This was particularly apparent during the contentious 2009 Iranian presidential election, when foreign correspondents were banned from the country, local media was under governmental control and opposition journalists were imprisoned. Te rest of the world-and indeed many Iranians-only knew about the demonstrations and the violent crackdown due to the images and reports uploaded on personal blogs, social websites or sent directly to international media. Te video of the dying Neda Agha Soltan, a student who was shot by the Basij militia, became the iconic image for the opposition movement in Iran. Te video was taken on a mobile phone, and to avoid censorship, emailed to an Iranian expatriate in the Netherlands, who uploaded it on YouTube and Facebook, and sent it to various international media outlets, which showed it immediately. Millions of people around the world watched it, and its popularity forced world leaders as well as the Iranian government to publicly comment on political developments in Iran.

\section{The Risks of Citizen Journalism}

According to Bowman and Willis (2003) "the intent of [a citizen's] participation is to provide independent, reliable, accurate, wide-ranging and relevant information that a democracy requires". However, due to the fact that in general citizen journalists are not professionally trained-or simply do not have these intentions - not all contributions from citizen journalists adhere to ethical standards that can be expected of professional journalists. Moreover, citizen journalists, especially those who write, usually give a very personal and therefore often biased view of an event. Some clearly identify their intentions - political or other-such as Indymedia

or Te Huffington Post; many mainstream news organizations indicate UGC, and whether this content can be verified by other sources. But others place personal accounts of citizens alongside reports from their staff, making it more difficult to distinguish amateur and therefore unchecked content from professional content, which has been checked for accuracy, objectivity, truthfulness and fairness. (Gillmor, 2006).

Many citizen contributors do not see themselves as journalists but rather as activists, and therefore do not believe they should adhere to media ethics. However, if their work is published in the media, it can have damaging effects, especially on sites where the editorial gatekeeping is left completely to the audience. One of the most striking examples for this was a report by an anonymous source, only identified as 'johntw', on CNN iReport on 3 October 2008 about Apple CEO Steve Jobs suffering a heart attack and being rushed to hospital. As there had already been concerns about Mr Jobs's health, Apple's stock prices sank to a 17-month low within minutes of the posting. Only when the blog Silicon Valley Insider rectified the information after having checked it with an Apple spokesperson, who had strongly denied the report, was the story brought to a halt and Apple's stocks slowly recovered. Te incident also damaged CNN iReport's reputation, although the site clearly states that only content marked 'CNN iReport' has been vetted. While this "news item" might have been relevant, it was neither reliable nor accurate, and since the author was anonymous, he or she could not be held accountable or responsible.

\section{Criticisms}

Many critics have stressed that anonymity in citizen journalism is one of its pitfalls, making it difficult and at times impossible to ensure that information is correct and that the author takes responsibility for the posting. As a result, the audience needs to be particularly careful when evaluating content from citizen 
journalists. While much of the credibility of citizen reports stems from being imperfect and biased, especially in the blogosphere, the fact is that the audiences have to stop being passive recipients of information and become active users of news if they want to benefit from citizen journalism, checking the facts they are given with other sources, online and offline. Dan Gillmor calls this creating a "hierarchy of trust".

\section{CONCLUSION}

Journalism has been deeply affected by the process of cultural globalization, in a far more complicated way than the early simplistic predictions would indicate. From citizenbased to corporate mainstream journalism, a proliferation of local projects has taken place around the world, even while forces of homogenization have provoked overblown and dark projections of Western capitalist media domination. But it is not enough to simply go country-by-country to observe the interesting ways journalism has adapted to change; the whole interest in globalization for many lies in its possibilities for adding some new transnational logic to existing cultural and national communities, and we hope that when applied to journalism this will be a more emancipatory than repressive impulse. We still need empirical work to examine these changes, but that will be a multilayered project.

The focus on 'global' news content-what it contains, who it reaches, and the elites who must engage with it-simply reminds us that a globalized journalism is increasingly not a respecter of national boundaries and must be conceptualized accordingly. Searching for the Global in Journalism When considering globalization and journalism, it is tempting to come up with new categories of media, practice, professionals, and content and elevate them to 'global' status. However, in order for citizen journalism to flourish, technological as well as cultural changes are needed. Te formerly passive audience needs to contribute actively to the news; on the other side, mass media have to accept the value of User Generated Content (UGC) and learn to incorporate it in an effective way.

\section{REFERENCES}

[1]. Aaron, B. (2010). "Citizen Journalists as Gatekeepers"-Routledge

[2]. Andrew K, (2007). "The Cult OF the Amateur" - how blogs, MySpace, YouTube, and the rest of today's user generate media are destroying our economy, our culture, and our values. Double DAY, USA. Ayo, \& Dele S. (2001). "The Media and Democratic Rule in Nigeria "in Development Management Network Bulletin, Volume XIII

[3]. Babalola, E. T. (2002). "Newspapers as Instruments for Building Literate Communities. The Nigerian Experience". Nordic Journal of African Studies. Bowman \& Willis, (2003). "We Media: How audiences are shaping the future of news and information". Washington DC: The media center at the American press institute. Country Profile, Reuters Institute for the Study of Journalism website. Oxford University, London. 2010. Dan Gillmor, (2004 ). "We the Media: Grassroots Journalism by the People, For the People. O' Reilly Media. Dan Gillmor, "Media active"- Citizen Journalism Defines the Future. USA

[4]. David, B. M. (2010). "What Citizen Journalism Can Learn From Public Journalism", in Public Journalism 2.0-The Promise and Reality of a Citizen- Engaged Press"- Routledge.

[5]. Deuze, M. (2009). "Te Future of Citizen Journalism", p. 259; C. W. Yang, "Citizen Journalism in South Korea", p. 145 in S. Allan and E. Torson

[6]. Donu, K. (2010). piece titled, "Still Standing but Standing Still", in BBC Focus on Africa magazine, OctDec edition. Fackson Banda, (2008). "Citizen Journalism \& Democracy in Africa"-An Exploratory Study. Highway Africa. Farooq, K. (2010). "What Virtual Nigeria Says About Real Nigeria". USA Africa Dialogue Series.

[7]. Fouhy, E. (2000). Which way will it go? American Journalism Review, 22 (2) 18-19 Gailey, Harry A. \& David T. ed. (1972). African post-colonial literature the encyclopedia Americana Vol. 20. New York: Hill and Wang,

[8]. Gillmor, D. (2006). We the Media, Sebastopol, CA: O'Reilly Media, Http://international.ohmynews.com/ for updated articles on citizen journalism from around the world. J. Rosen, www.pressthink.org.

[9]. Gillmor, D. (2007), pp. 1-4 for examples in the U.S.; also L. Salter, "Issues for Citizen

[10]. Journalism", in S. Allan and E. Torson (2009), p. 178. Greensdale, R. (2008). "Move Over: Journalists Will have to Share their Space", Sidney

[11]. Morning Herald, Nexis, UK base. Heikki , H. (2010). Lecturer, Journalism Department, Tampere University, Finland, in "Citizen Journalism Opening Up political Space in Africa'-Linu Atarah.

[12]. Helen Boaden, BBC Head of News, quoted in S.Allan and E. Torsen (2009), p. 4. 
[13]. Hope Eghagha, (2002). "The GSM Revolution" Published article on the net on ICT in Nigeria. Hudgens, Jim, \& Richard T. (1999).West Africa: The Rough Guide. 3rd ed. London: Rough Guides Ltd.

[14]. ITU 2010 Report. Jack, R. (2010). "Common Knowledge, Civic Engagement and Online News Organizations", in Public Journalism 2.0- The Promise and Reality of Citizen Engaged Press.

[15]. Salter, L. (2009). "Issues for Citizen Journalism", in S. Allan and E. Torson pp. 178-180. 